\title{
Developing Potential for Postsecondary Attainment: Measuring the Outcomes of an Evidence Based College Readiness Curriculum without the Fear of Statistics
}

\author{
Nicole G. DeRonck \\ Western Connecticut State University \\ 181 White Street \\ Danbury, CT 06810, USA \\ Rachelle Pérusse \\ University of Connecticut \\ Charles B. Gentry Bldg \\ 249 Glenbrook Rd \#3064 \\ Storrs, CT 06269, USA \\ Frank E. Staples \\ East Hartford Public Schools \\ 1110 Main Street \\ East Hartford, CT 06108, USA
}

\begin{abstract}
University faculty and school counselors-in-training collaborated with a school district to implement select lessons from an evidence-based intervention to improve college-going behaviors of 30 eight-grade students. Lessons were delivered and pre-post test data were collected as part of the district's comprehensive school counseling program. Post-tests revealed an increase in the percentage of students whom could identify their postsecondary goals after high school.Implications for school counselors relating to gains identified with uncomplicated data collection and stakeholder collaboration are discussed.
\end{abstract}

Keywords: school counseling, postsecondary, middle school, collaboration, intervention, math anxiety, data collection, descriptive statistics

\section{Introduction}

Cook (2015) suggests that at the middle school level, the focus of college readiness should be on teaching collaboration, communication, creative thinking, critical thinking, problem solving, decision making, evaluation, argument, and organization. For many students, it is challenging to think meaningfully about events that are potentially six years or further into the future (Cook, 2015). However, students may be able to better meet college readiness standards in high school (Balfanz, 2009). This preparation includes the knowledge, skills, and behaviors necessary to successfully complete a college course, and be able to move on to the next course level in the subject area (Conley, 2011). The benefits of exposing school-aged students to college and career information is that it opens the door to higher levels of occupation and socioeconomic status (Pérusse, DeRonck \&Parzych, 2017).Student success in the first year of postsecondary education is largely dependent on developing greater college readiness skills at the secondary level (Complete College America, 2012).School counselors are prepared to assist students with developing college and career readiness skills through the implementation of a comprehensive school counseling program (American School Counselor Association (ASCA), 2019). School counselors are expected to collect data to monitor progress, evaluate programs, and identify achievement gaps when students are not performing at the same rate as their peers (ASCA, 2019). School counselors ensure all students are on track to become college and career ready by collecting data (ASCA, 2019). However, there are a small number of counselors who actively collect data due in part to low self-efficacy around math skills and the perception that data collection is a central office function (Holcomb-McCoy, Gonzalez, Johnston, 2009). Math anxiety is the most prominent phobia that is connected to a knowledge based field (Luttenburger, Wimmer, \&Paechter, 2019). Math impacts people globally across all ages and has a higher prevalence rate in women than in men (Luttenburg et al., 2019), a fact that is important given that $73.3 \%$ percent of counselors identify as female (Data USA, 2019). Further, anxiety around taking statistics courses has been shown to impact college students' ability to learn and apply the course material (Siew, McCartney \&Vitevitch, 2019). The most effective intervention to address math anxiety is to dispel the myth that strong mathematical ability is required to analyze data (Siew et al., 2019). 


\section{Method}

\subsection{Intervention}

A series of classroom lessons related to college and career readiness was implemented at the middle school level. Pre and post data were collected as part of the lessons. University faculty worked to better support both graduate students in a counselor education program and in-service counselors in understanding how to collect and use data to monitor outcomes of a school counseling intervention without the use of inferential statistics. The use of simplified data can indicate a move in the level of student progress. For this reason, the results of the intervention will be reported using descriptive statistics.

Using select lessons from the curriculum designed through the Center for Educational Partnerships at UC Berkeley in cooperation with the Educational Credit Management Corporation (ECMC) Foundation, university school counseling students delivered classroom guidance and/or group counseling lessons to address college and career readiness in a local school district. The Realizing the College Dream curriculum is evidence based and was designed to help middle school students view themselves as having the potential to attend a post-secondary institution of their choice such as a university, college, or technical school and understand that it can be affordable (Center for Educational Partnerships, 2018). The goal of the curriculum, according to The Center for Educational Partnerships (2018), is "to increase the expectations of attending college by low-income, first-generation college-going students and their families (p. 1)". The curriculum is free and can be downloaded from the Center for Educational Partnerships' website, www.ecmc.org.

As part of their practicum experience at their site, school counseling students delivered a series of four lessons from the Realizing the College Dream Curriculum (https://www.ecmc.org/students/realizing-the-college-dream.html; Center for Educational Partnerships, 2018), that focused on thinking about being a college student, career exploration and identifying and planning for future goals (see Table 1). The specific lessons were chosen because of the alignment with the College Board's National Office of School Counselor Advocacy (NOSCA) identified Eight Components of College and Career Readiness Counseling. Some modifications were made to incorporate the college readiness skills for middle school students suggested by Cook (2015) as well as to fit constraints imposed by the partnering school district such as time and available technology. University faculty role played lessons with counselors in training during practicum supervision. School counselors in the partnering district delivered the lessons along with the school counselors-in-training.

Table 1. Lessons used in intervention

\begin{tabular}{|c|c|c|c|}
\hline Lesson & Topic & $\begin{array}{l}\text { Original ECMC } \\
\text { Curriculum } \\
\end{array}$ & Modification \\
\hline 1 & $\begin{array}{l}\text { Where do I see myself in } 10 \\
\text { years }\end{array}$ & $\begin{array}{l}\text { A1. Part } 1 \text { Dream a } \\
\text { Little Dream }\end{array}$ & $\begin{array}{l}\text { Addition of a scripted guided } \\
\text { imagery focusing on careers } \\
\text { in the future and related } \\
\text { subjects of study. }\end{array}$ \\
\hline 2 & $\begin{array}{l}\text { What will it cost me to support } \\
\text { myself in my ideal vision of } \\
\text { my future }\end{array}$ & $\begin{array}{l}\text { A.1 Part } 2 \text { Future } \\
\text { Spending }\end{array}$ & $\begin{array}{l}\text { Average costs for each item } \\
\text { on worksheet were provided } \\
\text { to facilitator rather than } \\
\text { having students research } \\
\text { information to make it more } \\
\text { middle school aged } \\
\text { appropriate, to save time and } \\
\text { to address lack of available } \\
\text { technology. }\end{array}$ \\
\hline 3 & $\begin{array}{l}\text { Career Interest Survey } \\
\text { What careers are of interest to } \\
\text { me and what do I know about } \\
\text { them from family and friends? }\end{array}$ & $\begin{array}{l}\text { A.2. Parts } 1,2 \& 4 \\
\text { Career Interests }\end{array}$ & $\begin{array}{l}\text { Removed part } 3 \text { as a separate } \\
\text { lesson due to time constraints. }\end{array}$ \\
\hline 4 & $\begin{array}{l}\text { In what career clusters and } \\
\text { college majors do my interests } \\
\text { fall? } \\
\text { How do I set a goal to help me } \\
\text { get involved in an activity now } \\
\text { that will support my interests? }\end{array}$ & $\begin{array}{l}\text { A.2 Part } 3 \text { Career } \\
\text { Clusters \& SMART } \\
\text { Goals }\end{array}$ & $\begin{array}{l}\text { Addition of SMART goal } \\
\text { planning activity }\end{array}$ \\
\hline
\end{tabular}




\subsection{Data Collection}

School counselors-in-training worked in partnership with their site supervisors to collect pre and post-test data as part of the partner school's comprehensive school counseling curriculum protocol (see appendix A for assessment tool). Perception data pertaining to career orientation and feedback on each lesson was also collected. The school district partner has an established Comprehensive School Counseling Program that is aligned with the Connecticut and National models. The school district partnercreated the survey, collected and took ownership of the data to measure the impact of the lessons on student achievement as part of their comprehensive school counseling program. District school counselors collected pre/post test data on the four lesson unit conducted by the school counselors in training, as well as feedback on the each of the individual lessons. University faculty and students assured collaboration took place, and that the district helped determine what data to collect. This made for a partnership based on helping the site supervisors learn more about data collection. An emphasis was placed on how to use the findings without the use complex statistical analysis. Data was analyzed using only descriptive statistics.

\subsection{Participants}

The participants included 30 students in grade 8 who were located in a school district where there is a high percent of students who receive free and reduced lunch (65.4\%) and 59.6\% of students pursuing a college education (Connecticut State Department of Education, 2018). District school counselors acknowledged that the curriculum was in-line with their student population and designed for their student population.Lessons were provided in several schools across the district. There was no risk to the students involved.

\section{Results}

\subsection{Pre-Test Results}

School counselors at the site collected the pre-test and post-test data. There were a total of 30 eighth grade students that participated and in the school district's program to solidify their post-secondary plans and their long term plans for thefuture. The majority of students responded that they planned to attend a two or four year college. Activities in the "other" category included various types of work and leisure activities such as travel and professional athlete.According to the school counseling team, all of the students were able to identify at least one field of interest and indicated that they felt their current career interests would support their desired lifestyle. However, when asked how much they thought they would make in their career of interest, students appeared to be misinformed or had no idea what the average salary for their chosen field might be. For example, a student who indicated they wanted to be a nurse responded that she will make $\$ 50,000$ bi-weekly. Another student indicated that as a psychiatrist she anticipated making $\$ 30$ per hour.

When asked about STEM (Science, Technology, Engineering, Math) career awareness, $40 \%$ of the students indicated they knew what the acronym STEM represented. Additionally, only half of the students indicated they had heard of SMART goals. SMART is an acronym for goals that are specific, measurable, attainable, realistic, and timely (Lawlor\&Hornyak, 2012). SMART goals were used because they can contribute to student learning outcomes when used in the classroom setting (Lawlor\&Hornyak, 2012). Regarding postsecondary plans, $17 \%$ of students indicated they did not know what they wanted to do. The majority of students responded that they planned to attend a two or four year college (53\%). The remainder of students indicated interest in the military (13\%) or other activities (17\%). Activities in the "other" category included various types of work and leisure activities such as travel and professional athlete.

\subsection{Post-Test Results}

Following the intervention, middle school students were given a post-test. Results indicated that $100 \%$ of the students were able identify what the STEM acronym represented and how to write a SMART goal. Student responses regarding income and lifestyle were considerably more informed with several students citing the activity in lesson 2 on future spending. The most striking data from the assessment was that the percentage of students who indicated they did not know what they might like to do beyond high school decreased from 17\% to zero. This indicates that students had formulated a tentative plan for their future. There was an eight percentage point gain in students interested in attending college and six percentage point gain in plans for pursing the military as an option after graduation.Results of a T-Test analysiscomparing pre-test and post-test results suggest that the intervention did not have an effect on the student's plans for the future (See Table 2). 
Table 2. T-Test Results for Intervention

\begin{tabular}{llll} 
Group & Mean & Standard Deviation & $\mathrm{P}(p<.05)$ \\
\hline Pre-Test & 30 & 5.68 & 1.960 \\
& & & 1.960
\end{tabular}

\section{Implications for School Counselors}

School counselors are prepared to assist students in college and career counseling and can take the lead in preparing students to be college and career ready by implementing systematic interventions, and measuring the outcomes (Pérusse, DeRonck \&Parzych, 2017). Anxiety around data analysis, and clerical duties may discourage counselors fromcollecting data as a matter of practice (Holcomb-McCoy et al., 2009; Viera\& Freer, 2015). Therefore, it is imperative that school counselors recognize that the ability to perform statistical analysis are not necessary to identify student progress. The findings in this study suggest that using descriptive statistics can reveal gains in student learning without the fear of statistics.Moving the needle on postsecondary awareness does not have to be complicated. A planned interventioncan provide an indication of student learning when simplified data is collected and analyzed. For example, data might include a survey administered to students and faculty, information from existing sources such as grades or test scores, information gained from collaborating with teachers, and/or creating targeted questions specific to an intervention. Examining the aforementioned data points can be completed without the use of complex statistical analysis. Further, in this example, relying solely on the use of statistical analysis in this intervention (i.e., T-test) would have caused the school counselors to miss the fact that they did indeed make a difference for $17 \%$ of the $8^{\text {th }}$ graders who participated. Moreover, descriptive data is necessary for counselors to implement and monitor closing the gap activities as prescribed by the ASCA National Model (2019).

This intervention also highlights that using a collaborative process to intervene has benefits beyond student outcomes (Cook, Krell, Hyden, Garcia \&Denitzio, 2016, National Association of Professional Development Schools, 2017). A school district-university team committed to the preparation of counselors-in-training that actively engages in the school community leads to school counselors that are better prepared to meet the demands of the job (Pérusse et al., 2017). Counselor educators and practicing school counselors gain the opportunity to stay current by working together to impact students.

\section{Limitations}

Counselors had access to a limited sampling of the $8^{\text {th }}$ graders across the district.Additionally, data was not collected to measure neither the self-efficacy of the counselors' math ability nor their math anxiety levels. A suggestion for further study would be survey counselors using a pre-post rating scale to identify measure math anxiety levels before and after the data collection and analysis using a similar intervention.

\section{References}

American School Counselor Association (ASCA) (2019). ASCA national model: A framework forschool counseling programs $\left(4^{r d} E d\right.$. $)$. Alexandria, VA: American School Counselor Association.

Balfanz, R. (2009). Putting middle grade students on the path to graduation: A policy and practice brief. Westerville, OH: National Middle School Association.

Center for Educational Partnerships (2018). Realizing the college dream: Teacher advisor guide. Berkeley, California: University of California. Retrieved from http://cep.berkeley.edu/sites/default/files/pdf/realizing_the_college_dream.pdf

Complete College America (2012). Remediation: Higher education's bridge to nowhere. Washington, D.C.: Author.

Conley, D.T. (2011). Redefining college readiness. Eugene, OR: Educational Policy

Cook, A.L., Krell, M.M, Hayden, L.A, Garcia, R., \&Denitzio, K. (2016). Fieldwork using the professional development model: Developing social justice orientation and multicultural competency. Journal of Multicultural Counseling and Development, 44, 176-188.

Cook, B. (2015, 15 May). College and career ready: What it means for middle school students. AMLE Magazine, 2(9), 24-26.

Data USA (2019, June 6). Data USA counselors. Retrieved from https://datausa.io/profile/soc/counselors\#demographics 
Holcomb-McCoy, C., Gonzalez, I. \& Johnston, G. (2009). School counselor dispositions as predictors of data usage. Professional School Counseling, 12(5), 343-351.

Lawlor, K.B. \&Hornyak, M.J. (2012). Smart goals: How the application of smart goals can contribute to achievement of student learning outcomes. Developments in Business Simulation and Experiential Learning, 39, 259-267.

Luttenburger, S., Wimmer, S., \&Paechter, M. (2019). Spotlight on math anxiety. Psychological Research and Behavior Management, 11,311-322.

National Association of Professional Development Schools (PDS). (2017). What it means to be a National Professional Development School. Retrieved from https://napds.org/nine-essential/

Pérusse, R., DeRonck, N., \&Parzych, J. (2017). School counseling: Partnering with a school district to provide postsecondary opportunities for first generation, low income, and students of color. Psychology in the Schools, $54,1222-1228$.

Viera, C.A. \& Freer, K. (2015). Barriers and enablers to data-driven decision making by high school counselors and advisors. Performance Improvement, 54(10), 30-40.

Siew, C. S. Q., McCartney, M. J., \&Vitevitch, M. S. (2019, January 10). Using network science to understand statistics anxiety among college students. Scholarship of Teaching and Learningin Psychology. Advance online publication http://dx.doi.org/10.1037/st10000133

\section{Appendix A}

\section{Pre/Post Assessment Tool}

PRE/POST - How Much Do I Know About My Future Goals

Name:

Grade:

Date:

School you attend:

Please answer the questions the best you can. Please write "I don't know" if you are not sure. This test is not part of your grade. The goal is to see how much you will learn from the time we start our lessons to the time we finish.

1. I know what a SMART Goal is. YES MAYBE NO

2. I am able to write a SMART Goal* YES MAYBE NO

3. I know what STEM means YES MAYBE NO

4. What is your current career goal?

5. My career interests fall in these career clusters:

O

$\circ$

○

○

6. How much money do you think you will make in that career?

7. Please list at least 3 things that are important to you about what you want to have when you are grown up and living on your own: (you can continue on the back of this page if you want) 
○

○

8. I believe that the career I am interested in right now will support the lifestyle I described above.

YES MAYBE NO

9. Has anything about your future goals or plans changed from the beginning of the group? If yes, what changed?

10. What are your plans after high school? (Use the back of this page if you need to)

*Students were asked to produce sample SMART Goals within the context of the lessons. Counselors worked with students to assure they understood the format and could produce a SMART goal on their own. 